\title{
G20 Framework for Strong, Sustainable, Balanced and Inclusive Growth: German Presidency Outcomes and Recommendations for the Argentinian Presidency ${ }^{1}$
}

\author{
I. Prilepskiy
}

Ilya Prilepskiy - Candidate of Science (Physics and Mathematics), Head of Global Economy Division, Economic Expert Group; Participant at G20 Framework Working Group Meetings in 2013-2017 (as a member of the Russian ministry of finance delegation); Senior Researcher, Centre for Budget Analysis and Forecasting, Financial Research Institute; 3 Building 2, Nastasiynsky Side-Street, 127006 Moscow, Russian Federation; E-mail: iprilepskiy@eeg.ru

\begin{abstract}
The Framework for Strong, Sustainable and Balanced Growth was adopted by the Group of 20 (G20) in 2009. It contains a wide range of commitments, including the use of fiscal, monetary and structural policies to support growth of gross domestic product (GDP), ensuring trade and investment openness and reducing global imbalances. The Framework's target areas evolve according to global economic conjunctures and the priorities of the presidency. This article studies the main outcomes of the G20's work in 2017 in the context of this evolution, accounting both for the German presidency's Framework priorities (resilient and inclusive growth) and elements of agendas in recent years (fiscal strategies, growth strategies and the enhanced structural reform agenda-ESRA). The findings indicate that the $G 20$ indeed increased its focus on resilient and inclusive growth after concentrating mostly on growth rates in recent years. This is confirmed by the adoption of resilience principles as well as by an increase in the number of corresponding measures in growth strategies. With respect to previous agendas, G20 members succeeded in reducing fiscal risks, implementing growth strategy commitments and ESRA priorities. Still, estimates by the International Monetary Fund (IMF) and the Organisation for Economic Co-operation and Development (OECD) show that the G20 is unlikely to reach its goal of increasing collective GDP by $2 \%$ by 2018 through growth strategy measures. Another problem is that international organizations (IOs) do not fully capture the positive effects of G20 commitments on growth and inclusiveness. Overall, to reduce risks of a fall in the G20's credibility, the Argentinian presidency should maintain a focus on resilience and inclusiveness, elaborate a communication strategy for the G20's successes and intensify collaboration with IOs.
\end{abstract}

Key words: G20; global governance; international organizations; macroeconomic coordination; inclusive growth; resilient growth

For citation: Prilepskiy I. (2018) G20 Framework for Strong, Sustainable, Balanced and Inclusive Growth: German Presidency Outcomes and Recommendations for the Argentinian Presidency. International Organisations Research Journal, vol. 13, no 2, pp. 42-59 (in Russian and English). DOI: 10.17323/1996-78452018-02-03.

${ }^{1}$ The editorial board received the article in November 2017. 


\section{Introduction}

The Framework Agreement for Strong, Sustainable and Balanced Growth (SSBG) was adopted by the Group of 20 (G20) at the Pittsburgh summit in September 2009. Concerning the mechanisms of its implementation, leaders committed to develop a process to set out the objectives, put forward policies to achieve those objectives and collectively assess progress [G20 Leaders, 2009]. Key priorities included: implementation of responsible fiscal policies, attentiveness to short-term flexibility considerations and longer-run sustainability requirements; strengthened supervision of the global financial system; promotion of a more balanced current account, support of open trade and investment and rejection of protectionist measures; safeguarding price stability and promotion of market-based exchange rates; undertaking structural reforms to increase potential growth rates; and promotion of sustainable development and poverty reduction.

The all-encompassing nature of the Framework determines its key role in the work of the G20's finance track ${ }^{2}$ and the content of documents adopted at the annual leaders' summits. For instance, Framework issues represented 54\% of the volume of the Antalya Action Plan (2015); the figures for the Hangzhou Action Plan (2016) and the Hamburg Action Plan (2017) are 69\% and $42 \%$ respectively. It also accounts for changes to key discussion points depending on the global economic conjuncture and priorities of the presidency (such changes also take place in the G20's agenda as a whole; see Larionova [2012]). This paper assesses the successes and gaps of the German presidency in the context of this evolution, and offers recommendations for the Argentinian presidency in 2018. The objectives include: analysis of work on the Framework from 2009-2016, emphasizing key priorities and mechanisms; review of the process and results of the resilience and inclusiveness agendas selected by Germany to reflect its Framework priorities [G20 Presidency, 2016]; assessment of progress on priorities adopted by previous presidencies; and determination of possible priorities for 2018, taking into account the current global conjuncture and progress on earlier commitments as well as remaining gaps.

\section{Evolution of Work on the Framework Agreement in 2009-2016}

The evolution of both the Framework's policy focus and its key mechanisms is analyzed in Table 1. Several observations can be derived from this analysis. In the context of declining incentives for cooperation due to the absence of an explicit risk of a new global crisis like that of 2008-2009 [Callaghan, 2014], the G20 ensured macroeconomic coordination by adopting clear policy strategies and a collective numerical goal. Coordination momentum was underlined by introducing the G20's own accountability assessment methodology, the results of which reflect a G20 consensus rather than the positions of international organizations (IOs). Nevertheless, IOs retain an important role in the advancement of the Framework, both preparing analytical materials for the widening agenda and helping to assess progress in the implementation of commitments. Cooperation with the International Monetary Fund (IMF), the Organisation for Economic Co-operation and Development (OECD) and the World Bank was particularly active (the same is true for the G20 agenda as a whole; see Larionova [2017]).

Additionally, the Framework agenda underwent a significant expansion, largely through the addition of inclusiveness and environmental sustainability. The number of commitments and the complexity of their assessment increased markedly. In terms of the Framework's focus, at the most general level, the emphasis on supporting short-term growth and reducing imba-

${ }^{2}$ This involves discussions of macroeconomic and financial topics by finance ministers and central bank governors prepared by deputy ministers/governors with the support of G20 working groups on framework, investment and infrastructure and international financial architecture. 
lances decreased in favour of ensuring higher medium-term and potential growth. In terms of policy areas, this meant an ever-increasing emphasis on structural reforms.

The extent to which work on the Framework in 2017 matched the a forementioned trends, as well as the key results, is studied in the next section.

\section{Table 1. Evolution of Work on the Framework Agreement}

\begin{tabular}{|c|c|c|}
\hline Summit & Mechanisms & Policy Focus \\
\hline $\begin{array}{l}\text { Pittsburgh, } \\
\text { September } 2009\end{array}$ & $\begin{array}{l}\text { - Framework Agreement is adopted } \\
\text { - finance ministers and central bank governors } \\
\text { are tasked with elaborating the Mutual } \\
\text { Assessment Process for commitment } \\
\text { implementation assessment (MAP) with the } \\
\text { participation of IOs by November 2009 [G20 } \\
\text { Leaders, 2009] }\end{array}$ & $\begin{array}{l}\text { - avoidance of a premature exit from } \\
\text { macroeconomic stimulus } \\
\text { - elaboration of strategies for such an exit } \\
\text { - balanced growth: countries with persistent } \\
\text { current account (CA) surplus should adopt } \\
\text { measures to support domestic demand; } \\
\text { persistent deficit countries should increase } \\
\text { savings rate }\end{array}$ \\
\hline $\begin{array}{l}\text { Toronto, } \\
\text { June } 2010\end{array}$ & $\begin{array}{l}\text { - MAP is launched } \\
\text { - IMF presents scenario analysis showing the } \\
\text { benefits of structural reform acceleration } \\
\text { and risks of higher public debt and credit } \\
\text { deceleration [IMF, 2010] }\end{array}$ & $\begin{array}{l}\text { - focus shifts to fiscal consolidation due to } \\
\text { higher global GDP growth and rise in public } \\
\text { debt in advanced G20 economies; the latter } \\
\text { (except Japan) commit to at least halve } \\
\text { budget deficits by } 2013 \text { compared to } 2010 \text { and } \\
\text { ensure stabilization/reduction of public debt } \\
\text { (as \% of GDP) by 2016 [G20 Leaders, 2010] } \\
\text { - focus on reducing CA imbalances } \\
\text { is maintained }\end{array}$ \\
\hline $\begin{array}{l}\text { Seoul, } \\
\text { November } 2010\end{array}$ & $\begin{array}{l}\text { - country-specific SSBG commitments are } \\
\text { published for the first time } \\
\text { - agreement is reached on their monitoring } \\
\text { and on the need to elaborate indicators } \\
\text { of imbalances [G20 Leaders, 2010a] }\end{array}$ & $\begin{array}{l}\text { - focus on fiscal consolidation is maintained } \\
\text { - balanced growth agenda becomes more } \\
\text { prominent due to warnings [IMF, 2010a] } \\
\text { that CA imbalances may return to their pre- } \\
\text { 2008-2009 recession levels, when they were } \\
\text { among the key factors of crisis vulnerability }\end{array}$ \\
\hline $\begin{array}{l}\text { Cannes, } \\
\text { November } 2011\end{array}$ & $\begin{array}{l}\text { - indicators of imbalances are agreed upon in } \\
\text { April 2011 (CA balance; budget balance and } \\
\text { public debt; private debt and private savings } \\
\text { rate) and approved [G20 Leaders, 2011] } \\
\text { - based on indicators, the IMF prepares } \\
\text { sustainability reports [IMF, 2011] containing } \\
\text { diagnoses of the causes of imbalances and } \\
\text { recommendations for their elimination } \\
\text { - the IMF produces an assessment of Seoul } \\
\text { country commitments [IMF 2011a, 2011b] } \\
\text { - country commitments are updated }\end{array}$ & $\begin{array}{l}\text { - while maintaining the focus on CA } \\
\text { imbalances, special attention is again paid } \\
\text { to fiscal consolidation due to public debt } \\
\text { problems in the euro area [G20 Leaders, } \\
\text { 2011] }\end{array}$ \\
\hline $\begin{array}{l}\text { Los Cabos, } \\
\text { June } 2012\end{array}$ & $\begin{array}{l}\text { - the G20 adopts an accountability assessment } \\
\text { methodology [G20 Leaders, 2012] built } \\
\text { on the "country-owned, country-led" } \\
\text { principle; it includes self-accountability and } \\
\text { peer review and is based on the "comply or } \\
\text { explain" approach" } \\
\text { - the first report based on this methodology is } \\
\text { prepared; it stresses progress in commitment } \\
\text { implementation and reduction in imbalances, } \\
\text { but also focuses on the need to adopt new } \\
\text { growth-supporting measures }\end{array}$ & $\begin{array}{l}\text { - in the context of a deepening euro area } \\
\text { debt crisis and no space for fiscal stimulus } \\
\text { in many other economies, the number of } \\
\text { structural reform commitments increases } \\
\text { sharply (from } 56 \text { in } 2011 \text { to } 101 \text { ) }\end{array}$ \\
\hline $\begin{array}{l}\text { St. Petersburg, } \\
\text { September } 2013\end{array}$ & $\begin{array}{l}\text { - to maintain momentum on fiscal stability } \\
\text { [G20 Leaders, 2010] advanced G20 } \\
\text { economies and several emerging economies } \\
\text { adopt medium-term fiscal strategies for } \\
\text { stabilization/reduction of public debt [G20 } \\
\text { Leaders, 2013] } \\
\text { - finance ministers are tasked with developing } \\
\text { comprehensive growth strategies in time for } \\
\text { the } 2014 \text { summit [G20 Leaders, 2013] }\end{array}$ & $\begin{array}{l}\text { - the main focus is kept on fiscal consolidation } \\
\text { and structural reforms } \\
\text { - a new IMF report [IMF, 2013] identifies nine } \\
\text { economies as having persistent imbalances } \\
\text { (versus seven in 2011); however, it becomes } \\
\text { evident that overall imbalances remain lower } \\
\text { than before the crisis, which led to a weaker } \\
\text { emphasis on this agenda }\end{array}$ \\
\hline
\end{tabular}




\begin{tabular}{|c|c|c|}
\hline Summit & Mechanisms & Policy Focus \\
\hline $\begin{array}{l}\text { Brisbane, } \\
\text { November } 2014\end{array}$ & $\begin{array}{l}\text { - country commitments are reformatted into } \\
\text { growth strategies } \\
\text { - the G20 commits to raise collective GDP by } \\
2 \% \text { by } 2018 \text { through implementation } \\
\text { of growth strategies [G20 Leaders, 2014] } \\
\text { - accountability assessment methodology [G20 } \\
\text { Leaders, 2012] is reoriented toward growth } \\
\text { strategies } \\
\text { - the IMF and OECD are tasked with assessing } \\
\text { the impact of reforms on GDP and progress } \\
\text { in reaching the } 2 \% \text { goal }\end{array}$ & $\begin{array}{l}\text { - after fiscal stability goals were confirmed } \\
\text { in } 2013 \text {, and due to downgrades in potential } \\
\text { growth forecasts, the focus fully shifts } \\
\text { to structural reforms (four key areas: } \\
\text { promoting investment, employment, } \\
\text { competition and trade); members are advised } \\
\text { to include in the strategies measures } \\
\text { with the largest effect on GDP growth } \\
\text { by } 2018\end{array}$ \\
\hline $\begin{array}{l}\text { Antalya, } \\
\text { November } 2015\end{array}$ & $\begin{array}{l}\text { - peer review of the implementation of growth } \\
\text { strategies is carried out } \\
\text { - the IMF and OECD publish the first } \\
\text { assessment of progress on the } 2 \% \\
\text { commitment [IMF, OECD, 2015] } \\
\text { - countries develop investment strategies } \\
\text { with a focus on developing public-private } \\
\text { partnerships }\end{array}$ & $\begin{array}{l}\text { - structural measures remain the key focus } \\
\text { - need for optimizing fiscal composition is } \\
\text { highlighted, as it helps to raise GDP growth } \\
\text { without a worsening of fiscal balance } \\
\text { - the inclusiveness agenda, already key for G20 } \\
\text { sherpa track discussions, gains a major role in } \\
\text { the Framework for the first time; IOs produce } \\
\text { a paper highlighting inequality's negative } \\
\text { impact on growth [ILO, IMF, OECD, World } \\
\text { Bank, 2015]; countries add inclusiveness- } \\
\text { promoting measures to growth strategies [G20 } \\
\text { Leaders, 2015]; OECD positively assesses } \\
\text { effects of growth strategy measures on income } \\
\text { inequality [OECD, 2015] }\end{array}$ \\
\hline $\begin{array}{l}\text { Hangzhou, } \\
\text { September } 2016\end{array}$ & $\begin{array}{l}\text { - enhanced structural reform agenda (ESRA) } \\
\text { is approved [G20 Leaders, 2016; G20 } \\
\text { Framework Working Group, 2016]; } \\
\text { it contains nine priorities and corresponding } \\
\text { guiding principles to be used by members } \\
\text { when devising new measures and policy and } \\
\text { outcome indicators for structural reforms; } \\
\text { the OECD is tasked with assessing progress } \\
\text { on ESRA in } 2017 \\
\text { - the IMF is advised to expand analysis of } \\
\text { imbalances by including new indicators } \\
\text { - investment strategies are integrated into } \\
\text { growth strategies }\end{array}$ & $\begin{array}{l}\text { - several ESRA priorities duplicate those } \\
\text { in previous years; however, the inclusion of } \\
\text { new priorities (enhancing environmental } \\
\text { sustainability, encouraging innovation) leads } \\
\text { to a wider range of new measures in the } \\
\text { strategies [G20 Leaders, 2016a] }\end{array}$ \\
\hline
\end{tabular}

a The importance of the new methodology is underlined by empirical studies, as self-accountability promotes commitment implementation [Larionova, Rakhmangulov, Shelepov, 2016]. The role of IOs in MAP is now changed to analytical support of the new process and development of new versions of sustainability reports.

b The new format helped eliminate the criticism that the G20 does not place enough emphasis on monitoring commitment implementation [Schwanen, 2010] and does not produce ex-ante estimates of the impact of reforms on growth [Butler, 2012].

Source: G20 Summit documents, 2009-2016.

\section{Framework Priorities of the German Presidency}

The Framework priorities of the German presidency in 2017 were reflected in the resilience and inclusiveness agendas. Resilience means: the capacity to achieve sustainable growth in the face of risks and structural challenges; avoidance of build-up of risks, imbalances and vulnerabilities; and the ability to absorb and overcome shocks and return to a growth path [G20 Framework Working Group, 2017].

In December 2017, IOs presented policy papers on promoting resilience [BIS, 2016; IMF, 2016; OECD, 2016]. Key recommendations included: ensuring labour market flexibility and 
competitive product markets; safeguarding sustainability of public debt paths, implementation of fiscal rules and conservative fiscal projections; developing financial markets, monitoring financial imbalances and reducing tax incentives for private debt accumulation; ensuring price stability and transparency of central banks' communication strategies; and avoiding excessive accumulation of global imbalances, safeguarding trade and investment openness and promoting a more equitable distribution of globalization benefits.

The work of IOs formed the basis of the Note on Resilience Principles in G20 Economies approved at a ministerial level in March 2017 [G20 Framework Working Group, 2017; G20 Finance Ministers and Central Bank Governors, 2017]. It contains a set of 12 principles divided into "real sector," "public finance," "private finance," "monetary policy" and "external sector" sections corresponding to the aforementioned areas recommended by the IOs. Resilience principles serve as a complement to ESRA principles and may be utilized when formulating new measures supporting resilience (including measures for adjusted growth strategies) and conducting peer review of the strategies.

Because only three months had passed from the adoption of the principles to the presentation of the growth strategies, it is unlikely that the Note really influenced the G20's policy decisions in the run-up to the July 2017 summit. However, data presented in Table 2 indicate that members included almost 100 measures in the strategies that corresponded to one of the principles. Overall, measures on the "real sector" section dominated. As concerns Russia, there was one such measure - recapitalization of the Industry Development Fund which promotes resilience through economic diversification. Three commitments on financial sector resilience fell into the "private finance" category (discouraging malpractice in the financial market, enhancing investors' interest in the equity financing of public companies and development of the bonds market).

Table 2. The Number of New Measures in 2017 Growth Strategies Corresponding to Specific Aspects of Resilience

\begin{tabular}{|c|c|c|c|c|c|c|}
\hline Countries & Real Sector & $\begin{array}{l}\text { Public } \\
\text { Finance }\end{array}$ & $\begin{array}{l}\text { Private } \\
\text { Finance }\end{array}$ & $\begin{array}{c}\text { Monetary } \\
\text { Policy }\end{array}$ & $\begin{array}{c}\text { External } \\
\text { Sector }\end{array}$ & Total \\
\hline Argentina & 1 & & & & & 1 \\
\hline Australia & 4 & & & & & 4 \\
\hline Brazil & 2 & 2 & 5 & & & 9 \\
\hline Canada & 11 & & 1 & & 1 & 13 \\
\hline China & 2 & 1 & & & 2 & 5 \\
\hline EU & 4 & 1 & & & 1 & 6 \\
\hline France & 4 & 1 & & & 1 & 6 \\
\hline Germany & 1 & 5 & 1 & & & 7 \\
\hline India & 2 & & 3 & & & 5 \\
\hline Indonesia & 1 & 1 & & & & 2 \\
\hline Italy & 1 & 2 & & & & 3 \\
\hline Japan & 3 & & & 1 & & 4 \\
\hline Korea & 3 & & 2 & & & 5 \\
\hline Mexico & 1 & 1 & 1 & & & 3 \\
\hline Russia & 1 & & 3 & & & 4 \\
\hline Saudi Arabia & & 2 & & & & 2 \\
\hline
\end{tabular}




\begin{tabular}{|l|c|c|c|c|c|c|}
\hline \multicolumn{1}{|c|}{ Countries } & Real Sector & $\begin{array}{c}\text { Public } \\
\text { Finance }\end{array}$ & $\begin{array}{c}\text { Private } \\
\text { Finance }\end{array}$ & $\begin{array}{c}\text { Monetary } \\
\text { Policy }\end{array}$ & $\begin{array}{c}\text { External } \\
\text { Sector }\end{array}$ & Total \\
\hline South Africa & 2 & 1 & & & & 3 \\
\hline Spain & 2 & 1 & 2 & & & 5 \\
\hline Turkey & 1 & 1 & 1 & & & 3 \\
\hline UK & 4 & & & & & 4 \\
\hline U.S. & & 1 & & & 1 & 2 \\
\hline Total & 50 & 20 & 19 & 1 & 6 & 96 \\
\hline
\end{tabular}

Source: Author's calculations based on 2017 G20 growth strategies.

Regarding the second German priority, "inclusive" growth was added to the G20's main SSBG goals in December [G20 Presidency, 2016]. Thereafter, work proceeded in two strands . First, members were encouraged to add inclusiveness-promoting measures to adjusted growth strategies. Second, IOs were tasked with developing analytical papers on this topic.

Regarding country commitments, the number of new inclusiveness measures increased more than twofold (from 22 in 2016 to 46 in 2017, see Table 3). Russia inserted two additional policies promoting inclusiveness in its adjusted growth strategy, viz, increasing labour participation of vulnerable groups and improvement of financial inclusion for households and small and medium enterprises (SMEs).

Table 3. The Number of Measures Promoting Inclusiveness in 2016 and 2017 Growth Strategies

\begin{tabular}{|l|c|c|l|c|c|}
\hline \multicolumn{1}{|c|}{ Countries } & $\mathbf{2 0 1 6}$ & $\mathbf{2 0 1 7}$ & \multicolumn{1}{c|}{ Countries } & $\mathbf{2 0 1 6}$ & $\mathbf{2 0 1 7}$ \\
\hline Argentina & 1 & 2 & Japan & 1 & 1 \\
\hline Australia & 1 & 5 & Korea & 0 & 2 \\
\hline Brazil & 0 & 4 & Mexico & 0 & 0 \\
\hline Canada & 5 & 10 & Russia & 0 & 2 \\
\hline China & 2 & 2 & Saudi Arabia & 2 & 1 \\
\hline EU & 2 & 2 & South Africa & 0 & 1 \\
\hline France & 0 & 3 & Spain & 0 & 2 \\
\hline Germany & 0 & 3 & Turkey & 2 & 1 \\
\hline India & 3 & 2 & UK & 2 & 1 \\
\hline Indonesia & 1 & 1 & U.S. & 22 & 0 \\
\hline Italy & 0 & 1 & Total & & 46 \\
\hline
\end{tabular}

Source: Author's calculations based on 2016-17 G20 growth strategies.

Regarding the work of IOs, the IMF [2017] noted the decline in the global Gini coefficient due to convergence of per capita income between advanced and emerging economies; that said, within the first group income inequality grows while within the second group, the developments are mixed. Indices of "equal opportunities" improve as concerns access to finance and gender equality, but stagnate as concerns access to finance. Sources of inequality are both global (technological progress, globalization, financial integration) and national (labour mar- 
ket institutions, fiscal and education policies, access to finance). Inequality is shown to have a weak negative correlation with GDP growth. The OECD and the World Bank presented the framework for inclusive growth [OECD, World Bank, 2017] containing an explanation of the importance of links between inequality and growth, the impact of fiscal and structural policies on growth and inequality with a focus on the need for reform packages with positive effects on both GDP and inclusiveness, as well as key priorities for inclusiveness-promoting measures both at the G20 level and at the member level.

Concerning the assessment of progress on Germany's priorities, Tables 2 and 3 indicate the strong response of members to recommendations on inserting new measures promoting resilience and inclusiveness into growth strategies. However, the presidency's expectations that resilience principles would be applied in the peer review of progress on previous years' commitments did not materialize. Turning to the question of the conformity of Germany's 2017 results to the trends for 2009-2016 described above, the main points are as follows: the adoption of resilience principles confirmed the retention of cooperation momentum; the IMF, OECD and the World Bank continued their active participation in preparing analytical papers; inclusiveness became consolidated as one of the key elements of the finance track agenda; and approval of resilience principles, focusing to a large extent on ensuring macroeconomic and financial stability, served to rebalance the Framework agenda which had in recent years placed everlarger emphasis on structural reforms.

Apart from work on Germany's priorities, 2017 also saw the continued implementation of agenda items put forward by previous presidencies. These included fiscal strategies (Russia, 2013), growth strategies (Australia, 2014), ESRA and the call for more detailed study of imbalances (China, 2016). Analysis of progress and the results of this work are presented in the next section.

\section{Results of Work on Framework Agenda Items of Previous Years}

\section{Medium-Term Fiscal Strategies}

Apart from the U.S., G20 members continued to publish medium-term fiscal projections. Among advanced economies, those with public debt levels higher than $60 \%$ of GDP have already reduced this or plan to do so by 2018. Among emerging economies, only Brazil exceeds this threshold and the country's authorities expect the public debt to stabilize by 2020 .

\section{Growth Strategies}

At the Hamburg summit, G20 members put forward growth strategies for the fourth time. Since the time horizon that had been approved in 2014 was limited to 2018, the main focus of the strategies in 2017 was to communicate the progress made on previously adopted commitments. The results of the IMF-OECD qualitative assessment are presented in Table 4; they indicate significant advances in 2017. Regarding the quantitative assessment, IMF-OECD simulation results show that the impact of commitments completed by July 2017 on the G20's 2018 GDP amounts to $1.23 \%$.

Overall, 266 new measures were included in 2017, compared to 361 in 2016, 334 in 2015 and 1,028 in 2014. In the context of ESRA priorities, only "promoting inclusive growth" saw an increase in the number of commitments. If all new measures, as well as all in-progress commitments from previous years are fully implemented by the end of 2018, the resulting rise in the G20's 2018 GDP will amount to 0.15\% [IMF, OECD, 2017]. 
Table 4. Qualitative Progress on the Implementation of Commitments, $\%$

\begin{tabular}{|l|c|c|c|c|c|c|c|c|}
\hline & \multicolumn{4}{|c|}{ September 2016 Assessment } & \multicolumn{4}{c|}{ July 2017 Assessment } \\
\hline Year/Implementation Stage & $(1)$ & $(2)$ & $(3)$ & $(4)$ & $(1)$ & $(2)$ & $(3)$ & $(4)$ \\
\hline 2014 Measures & 55 & 43 & 2 & $<1$ & 61 & 35 & 3 & $<1$ \\
\hline 2015 Measures & 45 & 39 & 15 & 1 & 62 & 28 & 9 & 1 \\
\hline 2016 Measures & & & & & 36 & 62 & 2 & 0 \\
\hline
\end{tabular}

(1) fully implemented; (2) in-progress; (3) no/limited progress; (4) abandoned.

Source: [IMF, OECD, 2016, 2017].

\section{Enhanced Structural Reform Agenda}

In April 2017, the OECD published the first technical report on ESRA [OECD, 2017]. At the level of the G20, progress was noted on priorities "promoting trade and investment openness," "promoting fiscal reform," "improving and strengthening the financial system," "promoting competition and an enabling environment," "encouraging innovation" and "advancing labour market reform, educational attainment and skills." Developments on other priorities were more mixed. For "promoting inclusive growth," inequality continues to rise for certain members; for "improving infrastructure," public investment has been cut in many advanced economies; and for "enhancing environmental sustainability," there is a risk that the Paris climate agreement goals will not be met. Moreover, the OECD underlines the decline in the share of adopted recommendations from its Going for Growth report, interpreting this as a slowdown in political momentum for structural reforms.

The report also includes country-specific data on policy and outcome indicators. For Russia the data show: a slowdown in labour productivity in 2011-2016; a continued high labour participation rate; a stable Gini coefficient and investment share in GDP; an increase in research and development spending as a share of GDP; and improvement in "trading across borders" and "starting a business" indices from the Doing Business Report.

\section{IMF Report on Strong, Sustainable and Balanced Growth}

At the Hangzhou summit, leaders committed to continued analysis of imbalances with the help of the IMF [G20 Leaders, 2016a]. Germany suggested expanding this analysis, and in April 2017 the G20 tasked the IMF with producing the Report on Strong, Sustainable and Balanced Growth (IMF SSBG Report). It was published in October 2017 [IMF, 2017a] and addresses the questions of where the G20 is relative to its SSBG goals (diagnostics); which measures should be taken to achieve these goals (recommendations); and what benefits come from implementing recommendations (scenario analysis).

Analysis of the answers given in the report yields following results. Regarding diagnostics, as concerns "strong" growth, output gaps remain negative and inflation is too low in certain advanced economies. The impact of the commodity price shock is still felt in several emerging markets. Sustainability of G20 growth is under threat due to weak dynamics of potential output. Global imbalances are persistent and increasingly concentrated in advanced economies. Both public and private debt have risen significantly since the 2008-2009 crisis. 
In terms of recommendations, it was found that members' macroeconomic policy stances are generally appropriate (only two members were advised to change their monetary stance and seven members were advised to change their fiscal stance in 2017). Concerning structural measures, the IMF (taking into account the OECD's views) points to the significant benefits of implementing additional reforms over and above those included in the growth strategies.

With respect to scenario analysis, the key results of modeling the impact of in-progress structural commitments from the growth strategies as well as macroeconomic and structural recommendations by the IMF regarding the G20's GDP are presented in Table 5.

Table 5. Impact of Implementing IMF Recommendations on the G20's GDP Growth, \%

\begin{tabular}{|l|c|c|c|c|}
\hline & $\mathbf{2 0 1 7}$ & $\mathbf{2 0 1 8}$ & $\begin{array}{c}\text { Average } \\
\text { for 2019-2022 }\end{array}$ & $\mathbf{2 0 2 8}$ \\
\hline $\begin{array}{l}\text { Macroeconomic } \\
\text { Recommendations }\end{array}$ & 0.2 & 0.2 & 0.1 & 0 \\
\hline $\begin{array}{l}\text { In-progress Structural Measures } \\
\text { of the Growth Strategies }\end{array}$ & 0 & 0.1 & 0.3 & 0.4 \\
\hline Structural Recommendations & 0 & 0 & 0.4 & 3.0 \\
\hline Total & 0.2 & 0.3 & 0.8 & 3.4 \\
\hline
\end{tabular}

a Assumed to be fully implemented by the end of 2022.

b Implementation assumed to cover 2019-2028.

Source: [IMF, 2017a].

Overall, it may be concluded that progress was achieved in 2017 on the Framework agenda items retained from previous presidencies. G20 members once again confirmed their commitments to ensuring fiscal stability and increasing potential growth rates through structural reforms. IOs produced the assigned analytical papers. However, several gaps became evident which should be addressed by the Argentinian presidency. These include a likely failure to achieve the quantitative GDP goal and the absence of member-level data regarding the impact of the IOs' recommendations on growth. These are discussed in more detail in the following section.

\section{Recommendations for the Argentinian Presidency Concerning the Framework Agenda}

Global GDP growth in 2017 was sharply higher than in 2016 (3.7\% versus 3.2\%); for the first time since 2010, none of G20 economies was in recession. In 2018, growth is expected to accelerate further to $3.9 \%$ [IMF, 2018]. On the one hand, this creates favourable conditions for the implementation of the G20's structural reform agenda because the effect of measures to reduce excessive regulation of product and labour markets on GDP growth and inclusiveness is highest when demand growth rates are strong [IMF, 2015, 2016a]. On the other hand, better output dynamics may result in lessened attention paid by authorities to the resilience agenda; for instance, the IMF is apprehensive of initiatives by the U.S. administration for deregulation of the financial sector [IMF, 2017b].

Given "stronger" global growth, it is important to retain the focus in 2017 on "sustainable" and "balanced" growth in 2018. For instance, members should continue to be encour- 
aged to use resilience principles when developing new policies. Argentina's confirmed "Future of Work" priority aligns well with the inclusiveness agenda. Concerning the Framework, this priority may be reflected in assessments of the impact of technological progress on employment. Moreover, an analysis of the effects of the G20's collective financial inclusion agenda measures should be performed.

Concerning the agenda items from previous years, the main challenge in 2018 relates to the end of the horizon for the growth strategies. As described above, their implementation is adequate on a qualitative level. However, the probability of increasing the G20's GDP by 2\% by the end of 2018 through growth strategy measures is increasingly small. Corresponding joint IMF-OECD estimates show persistent declines (Fig. 1). Therefore, Argentina should develop a communication strategy for this "failure" and put forward proposals for future work on the growth strategies.

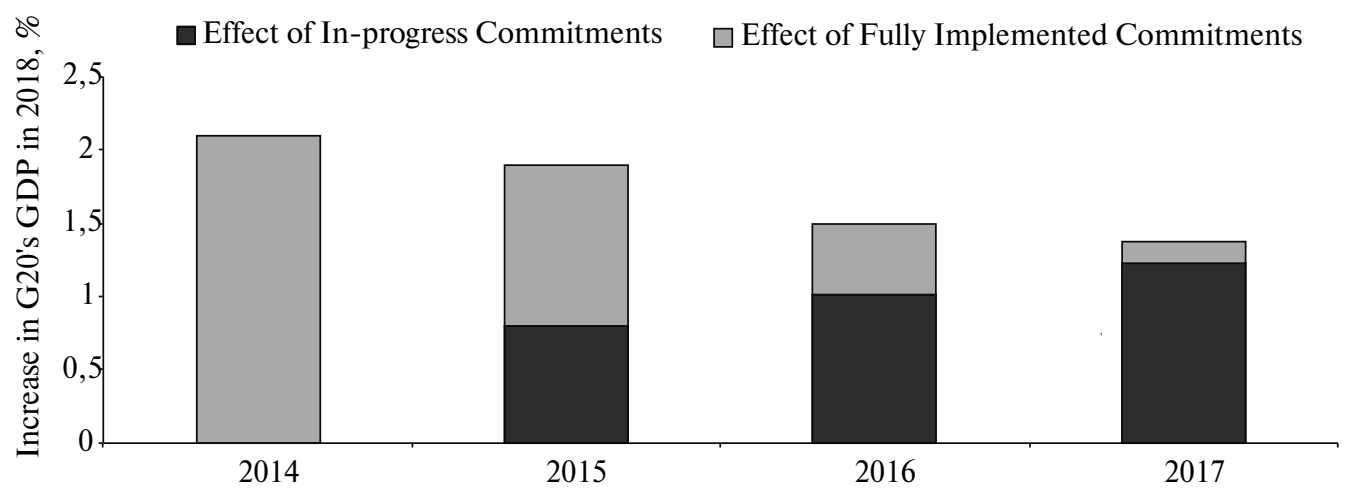

Fig. 1. IMF-OECD Estimates of the Impact of Growth Strategy Measures

Source: [IMF, OECD, 2014, 2015, 2016, 2017].

Concerning the communication strategy, it is important to stress the following points. First, the increase in the G20's GDP due to the implementation of growth strategies exceeded $\$ 1.3$ trillion. ${ }^{3}$ Second, the persistent decline in the impact estimate is not due to failures in the work of the G20, but rather to methodological problems. For example, in 2014 the IMF and OECD assumed that all measures would be fully implemented by the end of 2016, which contradicted actual timelines in the strategies. Third, the estimates by IOs should be treated as lower given that they take into account only the effects of structural measures and investment on potential GDP and do not include the effect of fiscal stimulus in certain economies on aggregate demand. Moreover, entire categories of structural reforms are omitted from quantitative assessment, including measures aimed at supporting exports. Overall, according to data presented by the IMF and OECD to the G20 Framework Working Group, the impact on GDP is estimated for less than $25 \%$ of growth strategy measures. Finally, the impact of implemented measures increases over time and will eventually exceed $2 \%$ of the G20's GDP even according to conservative IMF-OECD estimates [G20 Framework Working Group, 2017a].

Concerning the future work on the growth strategies, it seems prudent to apply the following approach. First, strategies should be retained as main member-level documents on the

${ }^{3}$ The estimate is based on the effect of measures deemed fully implemented by the time of the 2017 summit and the IMF's forecast for the G20's GDP in 2018 [IMF, 2017b]. 
Framework. Countries should continue to produce fiscal projections, while the format for implementation monitoring should be simplified using the IMF-OECD qualitative scale presented in Table 4. The number of new measures should be restricted, while the criteria for their inclusion should include the largest effects on growth, employment, inclusiveness, resilience and the priorities of other presidencies. This will help to make the strategies more focused currently, for some members, their volume exceeds 60 pages.

Second, no new quantitative goals should be adopted. The experience underlines the complexity of assessing the impact of reforms on growth. Furthermore, the effects of reforms are significantly influenced by demand conditions which are subject to unpredictable external shocks. In addition, a focus on inclusiveness and resilience presupposes the need for assessing a whole panel of indicators rather than a single indicator. The OECD technical report on ESRA is the best venue for such assessment; however, it requires certain modifications (see below). Third, the impact of reforms implemented in 2014-2018 on the G20's GDP should continue to be monitored in order to support the statement made in 2017 that this impact increases over time.

Several modifications should be made in the reports by IOs commissioned by the G20 in order to harmonize their key results with the needs of finance ministers and central bank governors. In the OECD technical report, 2014 data for all indicators should be inserted so that it is possible to assess their evolution from the start of the growth strategies' implementation. As concerns the IMF SSBG report, possible recommendations include: adding the inclusive growth aspect; expanding the sustainable growth aspect by accounting for financial and fiscal stability issues; inserting country-level effects of implementing the recommendations on GDP, budget balance, public debt, inflation and other indicators of particular interest for authorities; interacting with incoming presidencies to reflect their priorities in the report, noting that in 2017 the employment agenda (which is the priority in 2018) was assessed only superficially thereby reducing the report's value in helping countries to prepare growth strategies; reinstating the detailed analysis of the indicators of imbalances approved by G20 in 2011; and including an assessment of the impact on reaching the G20's growth goals of the G20's collective agenda of financial regulation and combatting base erosion and profit shifting (BEPS). The consensus reached in 2011 underlined the G20's commitment to a sustainable reduction in imbalances and for this reason the IMF's decision to drop detailed diagnostics and recommendations in 2017 is worrying.

\section{Conclusions}

The analysis carried out in this study indicates that in 2017, Germany achieved progress in modifying the Framework agenda. Encouraged by the presidency, members approved resilience principles and inserted new measures promoting resilience and inclusiveness in the growth strategies. Implementation of agenda items from previous years continues. Public debt dynamics have improved, the number of fully implemented growth strategy commitments has increased and reports assessing progress on structural reforms and reaching SSBG goals have been published.

Nevertheless, despite the progress achieved in 2017 and the acceleration in global growth, the Argentinian presidency faces several challenges. The assessment by the IMF and OECD that the goal of increasing the G20's GDP by $2 \%$ by 2018 through growth strategies will not be reached may reduce confidence in the effectiveness of the G20's work. Analytical papers by the IMF and OECD are not fully coordinated with Argentina's "Future of Work" priority, which worsens the prospects of adopting member-level measures in this area in 2018. There is 
a lack of transparent estimates of the benefits of collective action, which decreases incentives for cooperation.

Given the challenges, in order to increase the effectiveness of the G20's work in 2018, it is important to ensure agenda continuity, full and timely communication of G20 macroeconomic achievements, better cooperation between finance and sherpa tracks, especially on inclusiveness, and modification of IOs' analyses with the focus on country-level evolution of strong, sustainable, balanced and inclusive growth indicators, as well as on the effects of implementing the G20's collective agendas.

\section{References}

Bank for International Settlements (BIS) (2016) Economic Resilience: A Financial Perspective: A Note Submitted to the G20 on 7 November 2016. Available at: https://www.bis.org/publ/othp27.pdf (accessed 5 February 2018).

Butler C. (2012) The G-20 Framework for Strong, Sustainable, and Balanced Growth: Glass Half Empty or Half Full? Oxford Review of Economic Policy, vol. 28, no 3, pp. 469-492.

Callaghan M. (2014) The G20 Needs a Growth Strategy. Lowy Institute Policy Brief. Available at: https:// www.lowyinstitute.org/sites/default/files/callaghan_the_g20_needs_a_growth_strategy_finalweb_1.pdf (accessed 5 February 2018).

G20 Finance Ministers and Central Bank Governors (2017) Communiqué, G20 Finance Ministers and Central Bank Governors Meeting, 18 March. Available at: http://www.g20.utoronto.ca/2017/170318-finance-en. pdf (accessed 5 February 2018).

G20 Framework Working Group (2016) G20 Enhanced Structural Reform Agenda. Available at: www.mofa. go.jp/files/000185875.pdf (accessed 5 February 2018).

G20 Framework Working Group (2017) Note on Resilience Principles in G20 Economies. Available at: http:// www.bundesfinanzministerium.de/Content/DE/Standardartikel/Themen/Schlaglichter/G20-2016/NoteResilience-Principles-in-Economie.pdf?_blob=publicationFile (accessed 5 February 2018).

G20 Framework Working Group (2017a) Hamburg Accountability Assessment. Available at: http://www.bundesfinanzministerium.de/Content/DE/Downloads/G20-Dokumente/Hamburg_Genannte_Berichte/Hamburg-Accountability-Assessment.pdf?_blob=publicationFile\&v=2 (accessed 5 February 2018).

G20 Leaders (2009) Leaders' Statement: The Pittsburgh Summit, 24-25 September. Available at: http://www. g20.utoronto.ca/2009/2009communique0925.html (accessed 5 February 2018).

G20 Leaders (2010) The G20 Toronto Summit Declaration, 27 June. Available at: http://www.g20.utoronto. ca/2010/g20_declaration_en.pdf (accessed 5 February 2018).

G20 Leaders (2010a) The Seoul Summit Document, 12 November. Available at: http://www.g20.utoronto. ca/2010/g20seoul-doc.pdf (accessed 5 February 2018).

G20 Leaders (2011) The Cannes Action Plan for Jobs and Growth, 4 November. Available at: http://www.g20. utoronto.ca/2011/2011-cannes-action-111104-en.html (accessed 5 February 2018).

G20 Leaders (2012) The Los Cabos Growth and Jobs Action Plan, 19 June. Available at: http://www.g20.utoronto.ca/2012/2012-0619-loscabos-actionplan.pdf (accessed 5 February 2018).

G20 Leaders (2013) The St. Petersburg Action Plan, 6 September. Available at: en.g20russia.ru/load/782786923 (accessed 5 February 2018).

G20 Leaders (2014) Brisbane Action Plan, 16 November. Available at: http://www.g20.utoronto.ca/2014/brisbane_action_plan.pdf (accessed 5 February 2018).

G20 Leaders (2015) Antalya Action Plan, 16 November. Available at: http://www.g20.utoronto.ca/2015/ Antalya-Action-Plan.pdf (accessed 5 February 2018).

G20 Leaders (2016) G20 Leaders' Communiqué: Hangzhou Summit, 5 September. Available at: http://www. g20.utoronto.ca/2016/160905-communique.html (accessed 5 February 2018). 
G20 Leaders (2016a) Hangzhou Action Plan, 5 September. Available at: http://www.g20.utoronto. ca/2016/2016-09-08-g20-action-plan-en.pdf (accessed 5 February 2018).

G20 Presidency (2016) Priorities of the G20 2017 Summit, 1 December. Available at: http://www.g20.utoronto. ca/2017/2016-g20-praesidentschaftspapier-en.pdf (accessed 5 February 2018).

ILO, IMF, OECD, World Bank (2015) Income Inequality and Labour Income Share in G20 Countries: Trends, Impacts and Causes. Available at: https://www.oecd.org/g20/topics/employment-and-social-policy/ Income-inequality-labour-income-share.pdf(accessed 5 February 2018).

IMF (2010) G-20 Mutual Assessment Process - Alternative Policy Scenarios. Available at: https://www.imf. org/external/np/g20/pdf/062710a.pdf (accessed 5 February 2018).

IMF (2010a) G-20 Mutual Assessment Process - IMF Staff Assessment of G-20 Policies. Available at: https:// www.imf.org/external/np/g20/pdf/111210.pdf(accessed 5 February 2018).

IMF (2011) Staff Reports for the G-20 Mutual Assessment Process (MAP). Washington, DC: IMF. Available at: https://www.imf.org/external/np/g20/map2011.htm (accessed 5 February 2018).

IMF (2011a) G20 Economic Outlook: Analysis and Perspectives. Available at: https://www.imf.org/external/ np/g20/pdf/map2011/map.pdf (accessed 5 February 2018).

IMF (2011b) G20 Accountability Report. Available at: https://www.imf.org/external/np/g20/pdf/map2011/ account.pdf (accessed 5 February 2018).

IMF (2013) Update of Staff Sustainability Assessments for G-20 Mutual Assessment Process (MAP). Available at: https://www.imf.org/external/np/g20/map2013.htm (accessed 5 February 2018).

IMF (2015) Structural Reforms and Macroeconomic Performance: Initial Considerations for the Fund. Available at: http://www.imf.org/external/np/pp/eng/2015/101315.pdf (accessed 5 February 2018).

IMF (2016) A Macroeconomic Perspective on Resilience. Available at: http://www.g20.utoronto.ca/2017/2017Germany-IMF-a-macroeconomic-perspective-on-resilience.pdf (accessed 5 February 2018).

IMF (2016a) World Economic Outlook: Too Slow for Too Long. Available at: https://www.imf.org/en/Publications/WEO/Issues/2016/12/31/World-Economic-Outlook-April-2016-Too-Slow-for-Too-Long-43653 (accessed 5 February 2018).

IMF (2017) Fostering Inclusive Growth. Available at: https://www.imf.org/external/np/g20/pdf/2017/062617. pdf (accessed 5 February 2018).

IMF (2017a) G20 Report on Strong, Sustainable and Balanced Growth. Available at: https://www.imf.org/ external/np/g20/pdf/2017/100617.pdf (accessed 5 February 2018).

IMF (2017b) World Economic Outlook: Seeking Sustainable Growth. Available at: https://www.imf.org/en/ Publications/WEO/Issues/2017/09/19/world-economic-outlook-october-2017 (accessed 5 February 2018).

IMF (2018) World Economic Outlook Update: Brighter Prospects, Optimistic Markets, Challenges Ahead. Available at: https://www.imf.org/en/Publications/WEO/Issues/2018/01/11/world-economic-outlook-update-january-2018 (accessed 5 February 2018).

IMF, OECD (2014) Quantifying the Impact of G-20 Members' Growth Strategies. Available at: https://www. imf.org/external/np/g20/pdf/2014/growthstrat.pdf (accessed 5 February 2018).

IMF, OECD (2015) Quantifying the Implementation of G-20 Members' Growth Strategies. Available at: http:// g20.org.tr/wp-content/uploads/2015/11/Quantifying-the-Implementation-of-G-20-Members----GrowthStrategies.pdf (accessed 5 February 2018).

IMF, OECD (2016) Quantifying the Implementation and Impact of G-20 Members' Growth Strategies. Washington, DC: IMF.

IMF, OECD (2017) Quantifying the Implementation and Impact of G-20 Members' Growth Strategies. Available at: https://www.oecd.org/g20/topics/framework-strong-sustainable-balanced-growth/Quantifying-theImplementation-of-Growth-Strategies-2017.pdf (accessed 5 February 2018).

Larionova M. (2012) Supply-Demand Model for Developing a Presidency Proposals for Reform Agenda and Priorities in Informal International Institutions (G20, G8, BRICS). International Organisations Research Jour- 
nal, vol. 7, no 4, pp. 7-17 (in Russian). Available at: https://iorj.hse.ru/en/2012-7-4/70727384.html (accessed 5 February 2018).

Larionova M. (2017) G20: Engaging with International Organizations to Generate Growth. International Organisations Research Journal, vol. 12, no 2, pp. 54-86 (in Russian and English). DOI: 10.17323/1996-78452017-02-54.

Larionova M., Rakhmangulov M., Shelepov A. (2016) Explaining G20 and BRICS Compliance. International Organisations Research Journal, vol. 11, no 3, pp. 99-131 (in Russian and English). DOI: 10.17323/1996-78452016-03-99.

OECD (2015) Inequality and Inclusive Growth: Policy Tools to Achieve Balanced Growth in G20 Economies. Available at: https://www.oecd.org/g20/topics/framework-strong-sustainable-balanced-growth/Inequalityand-Inclusive-Growth-Policy-Tools-to-Achieve-Balanced-Growth-in-g20-Economies.pdf (accessed 5 February 2018).

OECD (2016) OECD G20 Policy Paper on Economic Resilience and Structural Policies. Available at: http:// www.g20.utoronto.ca/2017/2017-Germany-G20-policy-paper.pdf (accessed 5 February 2018).

OECD (2017) OECD Technical Report on Progress on Structural Reform Under the G20 ESRA. Available at: https://www.oecd.org/eco/growth/OECD-technical-report-progress-on-structural-reform-under-G20-ESRA-april-2017.pdf (accessed 5 February 2018).

OECD, World Bank (2017) A Policy Framework to Help Guide the G20 in its Development of Policy Options to Foster More Inclusive Growth. Available at: https://www.oecd.org/g20/topics/framework-strong-sustainable-balanced-growth/OECD-WBG-Policy-Framework-to-help-Gguide-the-G20-in-its-development.pdf (accessed 5 February 2018).

Schwanen D. (2010) The G20 Framework for Strong, Sustainable and Balanced Growth: A Study in Credible Cooperation. CIGI G20 Papers no 4. Available at: http://www20.iadb.org/intal/catalogo/PE/2011/08270.pdf (accessed 5 February 2018). 


\title{
Рамочное соглашение «Группы двадцати» об уверенном, устойчивом, сбалансированном и инклюзивном росте: итоги председательства Германии и рекомендации для председательства Аргентины ${ }^{1}$
}

\author{
И.В. Прилепский
}

Прилепский Илья Владимирович - к.ф.-м.н., руководитель направления «Международная экономика» Экономической экспертной группы; участник заседаний Рабочей группы по Рамочному соглашению «Группы двадцати» в составе делегации Министерства финансов РФ в 2013-2018 гг.; старший научный сотрудник Центра бюджетного анализа и прогнозирования Научно-исследовательского финансового института; Российская Федерация, 127006, Москва, Настасьинский переулок, д. 3, стр. 2; E-mail: iprilepskiy@ eeg.ru

Рамочное соглашение «двадиатки» было принято в 2009 г. Оно включает широкий спектр обязательств: использование мер бюджетной, денежно-кредитной и структурной политики для поддержкки роста ВВП; обеспечение открытости экономик для торговли и инвестиций; уменьшение глобальных дисбалансов. Акцент на отдельные элементы соглашения меняется в зависимости от ситуации в мировой экономике и позиции странпредседателей. В данной работе в контексте этой эволюции изучаются результаты работы «двадиатки» в 2017 г. как по приоритетам председательства Германии по повестке Рамочного соглашения (устойчивость и инклюзивность роста), так и по элементам повестки предыдущих председательств (бюджетные стратегии, стратегии роста, расширенная повестка структурных реформ). Показано, что внимание «руппы двадиати» $\kappa$ проблематике инклюзивного и устойчивого роста, а не только увеличения его темпов, как ранее, действительно повысилось. Это иллюстрируется принятием принципов устойчивости и увеличением числа соответствующих мер в стратегиях роста. В отношении повестки прошлых лет: бюджетные риски в странах «двадиатки» снижаются; доля исполненных обязательств стратегий роста растет; наблюдается прогресс и по расширенной повестке структурных реформ. Однако оценки МВФ и ОЭСР указывают на риски недостижения цели «двадиатки» по увеличению суммарного ВВП группы на 2\% к 2018 г. за счет мер стратегий роста. Другая проблема заключается в том, что аналитические бумаги международных организаций не в полной мере отражают положительные эффекты политики «двадиатки» на рост и инклюзивность. Соответственно, для снижения рисков уменьшения доверия к «Группе двадиати» председательству 2018 г. следует сохранить акценты на устойчивости и инклюзивности роста, разработать стратегию коммуникации успехов «двадиатки», интенсифицировать взаимодействие с международными организациями.

Ключевые слова: «Группа двадцати»; глобальное управление; международные организации; макроэкономическая координация; инклюзивный рост; устойчивый рост

Для цитирования: Прилепский И.В. (2018) Рамочное соглашение «Группы двадцати» об уверенном, устойчивом, сбалансированном и инклюзивном росте: итоги председательства Германии и рекомендации для председательства Аргентины // Вестник международных организаций. 2018. Т. 13. № 2. С. $42-59$ (на русском и английском языках). DOI: 10.17323/1996-7845-2018-02-03.

\section{Источники}

Ларионова М.В. (2012) Модель обеспечения баланса реальных и прогнозируемых внешних условий и национальных приоритетов страны-председателя для формирования предложений к повестке дня «Двадцатки», «восьмерки» и БРИКС // Вестник международных организаций. Т. 7. № 4. С. 7-17. Режим доступа: https://iorj.hse.ru/2012-7-4/70727384.html (дата обращения: 05.02.2018).

${ }^{1}$ Статья поступила в редакцию в ноябре 2017 г. 
Ларионова М.В. (2017) Группа двадцати» и международные организации: взаимодействие для обеспечения сильного, устойчивого и сбалансированного роста // Вестник международных организаций. Т. 12. № 2. C. 54-86. DOI: 10.17323/1996-7845-2017-02-54.

Ларионова М.В., Рахмангулов М.Р., Шелепов А.В. (2016) Что влияет на исполнение обязательств «Группы двадцати» и БРИКС: сравнительный анализ // Вестник международных организаций. 2016. T. 11. № 3. C. 99-131. DOI: 10.17323/1996-7845-2016-03-99.

Bank for International Settlements (BIS) (2016) Economic Resilience: A Financial Perspective: A Note Submitted to the G20 on 7 November 2016. Режим доступа: https://www.bis.org/publ/othp27.pdf (дата обращения: 05.02.2018).

Butler C. (2012) The G-20 Framework for Strong, Sustainable, and Balanced Growth: Glass Half Empty or Half Full? // Oxford Review of Economic Policy. Vol. 28. No. 3. P. 469-492.

Callaghan M. (2014) The G20 Needs a Growth Strategy. Lowy Institute Policy Brief. Режим доступа: https:// www.lowyinstitute.org/sites/default/files/callaghan_the_g20_needs_a_growth_strategy_finalweb_1.pdf (дата обращения: 05.02.2018).

G20 Finance Ministers and Central Bank Governors (2017) Communiqué, G20 Finance Ministers and Central Bank Governors Meeting. 18 March. Режим доступа: http://www.g20.utoronto.ca/2017/170318-financeen.pdf (дата обращения: 05.02.2018).

G20 Framework Working Group (2016) G20 Enhanced Structural Reform Agenda. Режим доступа: шжw. mofa.go.jp/files/000185875.pdf (дата обращения: 05.02.2018).

G20 Framework Working Group (2017) Note on Resilience Principles in G20 Economies. Режим доступа: http://www.bundesfinanzministerium.de/Content/DE/Standardartikel/Themen/Schlaglichter/G20-2016/ Note-Resilience-Principles-in-Economie.pdf?_blob=publicationFile (дата обращения: 05.02.2018).

G20 Framework Working Group (2017a) Hamburg Accountability Assessment. Режим доступа: http://www. bundesfinanzministerium.de/Content/DE/Downloads/G20-Dokumente/Hamburg_Genannte_Berichte/ Hamburg-Accountability-Assessment.pdf?__blob=publicationFile \&v=2 (дата обращения: 05.02.2018).

G20 Leaders (2009) Leaders' Statement: The Pittsburgh Summit. 24-25 September. Режим доступа: httр:// www.g20.utoronto.ca/2009/2009communique0925.html (дата обращения: 05.02.2018).

G20 Leaders (2010) The G20 Toronto Summit Declaration. 27 June. Режим доступа: http://www.g20. utoronto.ca/2010/g20_declaration_en.pdf (дата обращения: 05.02.2018).

G20 Leaders (2010a) The Seoul Summit Document. 12 November. Режим доступа: http://www.g20.utoronto.ca/2010/g20seoul-doc.pdf (дата обращения: 05.02.2018).

G20 Leaders (2011) The Cannes Action Plan for Jobs and Growth. 4 November. Режим доступа: http://www. g20.utoronto.ca/2011/2011-cannes-action-111104-en.html (дата обращения: 05.02.2018).

G20 Leaders (2012) The Los Cabos Growth and Jobs Action Plan. 19 June. Режим доступа: http://www.g20. utoronto.ca/2012/2012-0619-loscabos-actionplan.pdf (дата обращения: 05.02.2018).

G20 Leaders (2013) The St. Petersburg Action Plan. 6 September. Режим доступа: en.g20russia.ru/ load/782786923 (дата обращения: 05.02.2018).

G20 Leaders (2014) Brisbane Action Plan. 16 November. Режим доступа: http://www.g20.utoronto.ca/2014/ brisbane_action_plan.pdf (дата обращения: 05.02.2018).

G20 Leaders (2015) Antalya Action Plan. 16 November. Режим доступа: http://www.g20.utoronto.ca/2015/ Antalya-Action-Plan.pdf (дата обращения: 05.02.2018).

G20 Leaders (2016) G20 Leaders' Communiqué: Hangzhou Summit. 5 September. Режим доступа: httр:// www.g20.utoronto.ca/2016/160905-communique.html (дата обращения: 05.02.2018).

G20 Leaders (2016a) Hangzhou Action Plan. 5 September. Режим доступа: http://www.g20.utoronto. ca/2016/2016-09-08-g20-action-plan-en.pdf (дата обращения: 05.02.2018).

G20 Presidency (2016) Priorities of the G20 2017 Summit. 1 December. Режим доступа: http://www.g20. utoronto.ca/2017/2016-g20-praesidentschaftspapier-en.pdf (дата обращения: 05.02.2018). 
ILO, IMF, OECD, World Bank (2015) Income Inequality and Labour Income Share in G20 Countries: Trends, Impacts and Causes. Режим доступа: https://www.oecd.org/g20/topics/employment-and-socialpolicy/Income-inequality-labour-income-share.pdf (дата обращения: 05.02.2018).

IMF (2010) G-20 Mutual Assessment Process - Alternative Policy Scenarios. Режим доступа: https://www. imf.org/external/np/g20/pdf/062710a.pdf (дата обращения: 05.02.2018).

IMF (2010a) G-20 Mutual Assessment Process - IMF Staff Assessment of G-20 Policies. Режим доступа: https://www.imf.org/external/np/g20/pdf/111210.pdf (дата обращения: 05.02.2018).

IMF (2011) Staff Reports for the G-20 Mutual Assessment Process (MAP). Washington, DC: IMF. Режим доступа: https://www.imf.org/external/np/g20/map2011.htm (дата обращения: 05.02.2018).

IMF (2011a) G20 Economic Outlook: Analysis and Perspectives. Режим доступа: https://www.imf.org/exter$\mathrm{nal} / \mathrm{np} / \mathrm{g} 20 / \mathrm{pdf} / \mathrm{map} 2011 / \mathrm{map} . \mathrm{pdf}$ (дата обращения: 05.02.2018).

IMF (2011b) G20 Accountability Report. Режим доступа: https://www.imf.org/external/np/g20/pdf/ map2011/account.pdf (дата обращения: 05.02.2018).

IMF (2013) Update of Staff Sustainability Assessments for G-20 Mutual Assessment Process (MAP). Режим доступа: https://www.imf.org/external/np/g20/map2013.htm (дата обращения: 05.02.2018).

IMF (2015) Structural Reforms and Macroeconomic Performance: Initial Considerations for the Fund. Режим доступа: http://www.imf.org/external/np/pp/eng/2015/101315.pdf (дата обращения: 05.02.2018).

IMF (2016) A Macroeconomic Perspective on Resilience. Режим доступа: http://www.g20.utoronto. ca/2017/2017-Germany-IMF-a-macroeconomic-perspective-on-resilience.pdf (дата обращения: 05.02. 2018).

IMF (2016a) World Economic Outlook: Too Slow for Too Long. Режим доступа: https://www.imf.org/ en/Publications/WEO/Issues/2016/12/31/World-Economic-Outlook-April-2016-Too-Slow-for-TooLong-43653 (дата обращения: 05.02.2018).

IMF (2017) Fostering Inclusive Growth. Режим доступа: https://www.imf.org/external/np/g20/ pdf/2017/062617.pdf (дата обращения: 05.02.2018).

IMF (2017a) G20 Report on Strong, Sustainable and Balanced Growth. Режим доступа: https://www.imf. org/external/np/g20/pdf/2017/100617.pdf (дата обращения: 05.02.2018).

IMF (2017b) World Economic Outlook: Seeking Sustainable Growth. Режим доступа: https://www.imf. org/en/Publications/WEO/Issues/2017/09/19/world-economic-outlook-october-2017 (дата обращения: 05.02.2018).

IMF (2018) World Economic Outlook Update: Brighter Prospects, Optimistic Markets, Challenges Ahead. Режим доступа: https://www.imf.org/en/Publications/WEO/Issues/2018/01/11/world-economic-outlookupdate-january-2018 (дата обращения: 05.02.2018).

IMF, OECD (2014) Quantifying the Impact of G-20 Members' Growth Strategies. Режим доступа: https:// www.imf.org/external/np/g20/pdf/2014/growthstrat.pdf (дата обращения: 05.02.2018).

IMF, OECD (2015) Quantifying the Implementation of G-20 Members' Growth Strategies. Режим доступа: http://g20.org.tr/wp-content/uploads/2015/11/Quantifying-the-Implementation-of-G-20-Members---Growth-Strategies.pdf (дата обращения: 05.02.2018).

IMF, OECD (2016) Quantifying the Implementation and Impact of G-20 Members' Growth Strategies. Washington, DC: IMF.

IMF, OECD (2017) Quantifying the Implementation and Impact of G-20 Members' Growth Strategies. Режим доступа: https://www.oecd.org/g20/topics/framework-strong-sustainable-balanced-growth/Quantifying-the-Implementation-of-Growth-Strategies-2017.pdf (дата обращения: 05.02.2018).

OECD (2015) Inequality and Inclusive Growth: Policy Tools to Achieve Balanced Growth in G20 Economies. Режим доступа: https://www.oecd.org/g20/topics/framework-strong-sustainable-balanced-growth/ Inequality-and-Inclusive-Growth-Policy-Tools-to-Achieve-Balanced-Growth-in-g20-Economies.pdf (дата обращения: 05.02.2018).

OECD (2016) OECD G20 Policy Paper on Economic Resilience and Structural Policies. Режим доступа: http://www.g20.utoronto.ca/2017/2017-Germany-G20-policy-paper.pdf (дата обращения: 05.02.2018). 
OECD (2017) OECD Technical Report on Progress on Structural Reform Under the G20 ESRA. Режим доступа: https://www.oecd.org/eco/growth/OECD-technical-report-progress-on-structural-reform-underG20-ESRA-april-2017.pdf (дата обрашения: 05.02.2018).

OECD, World Bank (2017) A Policy Framework to Help Guide the G20 in its Development of Policy Options to Foster More Inclusive Growth. Режим доступа: https://www.oecd.org/g20/topics/framework-strong-sustainable-balanced-growth/OECD-WBG-Policy-Framework-to-help-Gguide-the-G20-in-its-development. pdf (дата обращения: 05.02.2018).

Schwanen D. (2010) The G20 Framework for Strong, Sustainable and Balanced Growth: A Study in Credible Cooperation. CIGI G20 Papers No. 4. Режим доступа: http://www20.iadb.org/intal/catalogo/ PE/2011/08270.pdf (дата обращения: 05.02.2018). 